\title{
発語失行と発声失行
}

\author{
日向 礼子
}

要 約：発声失行という用語は発語失行と比べると, 確立された概念とはいいがたく, その 報告数も少ない. 左 MCA 領域の脳梗塞により発声障害, 発語失行, 失語症を呈した症例を提 示し発声失行について検討した。本例は咳払いや笑うときには有響成分が見られた一方で，さ さやき声を呈した発声障害が 8 力月以上持続し, 構音レベルの失行症状の改善と解離していた。 鼻咽腔内視鏡検査にて, 発声時の声帯運動は一貫性に乏しく声帯が全く内転しないときや不自 然な声門閉鎖が見られるときがあった. 有声が見られるようになってからも一定しなかった. さらに発声時以外の意図的な咳払いや深呼吸時にも呼吸と声帯運動のタイミングのずれが観察 された. 声帯運動時の非一貫性や意図性と自動性の解離が明らかであり, 本例の発声障害は失 行症状の一つとして捉えられ, 声帯運動コントロールの高次中枢が障害されたものと考えられ た.

索引用語: 発声失行, 発語失行, ささやき声, 鼻咽腔内視鏡検査

\section{Apraxia of Speech and Apraxia of Phonation}

\author{
Reiko Hyuga
}

\begin{abstract}
As a general concept, apraxia of phonation is less established than apraxia of speech, and there are fewer reports as well. Here we present a patient of dysphonia who exhibited apraxia of speech and Broca aphasia due to cerebral infarction of the left MCA area; we examined the patient for apraxia of phonation. The patient whispered on a continuing basis for more than eight months. Meanwhile, voiced elements were in evidence when the patient laughed or coughed. Dysphonia was dissociated from improvement in articulation. Inspection by nasopharyngolaryngoscope revealed instances when vocal cord movements during utterances lacked consistency, or when there were unnatural glottal closures and non-adduction of the vocal cords. Deviation in the timing of breathing and vocal cord movements was also observed during intentional coughing and deep breathing other than for utterances. Non-consistency, and automatic and voluntary dissociation with vocal cord movements were clear; and these were viewed as a form of apraxia. These findings suggest that dysphonia in this patient is marked by impairment of control of the higher center of the vocal cords.
\end{abstract}

Key words : apraxia of phonation, apraxia of speech, whisper, nasopharyngolaryngoscope 


\section{はじめに}

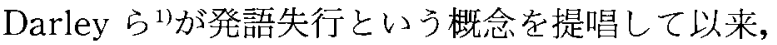
病栄 ${ }^{2-6)}$, 発話の聴覚印象分析など7-10), さまざまな角 度からの検討がなされてきた。特に 80 年代に入ってか らは，音響学的分析を用いた報告が見られ ${ }^{11-13) ， そ の ~}$ 発話特徵にはほぼ一致した見解がある。

一方で, 発声失行については、報告例も少なく ${ }^{14-16)}$,

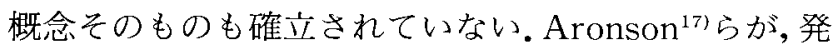
声と呼吸にかかわる失行として, 構音運動に発声はな いが、呼気流を伴うもの(ささやき声)，構音運動に全 く呼気流を伴わないものなどの類型を挙げている。し 加し Aronson らも, 発語失行の随伴症状なのか, もし くは発声失行が単独で起こりうるものかといったこと については言及していないようである。

そこで今回は, 構音レベルの失行の改善と比して, 発声レベルの異常が明らかに持続した症例について, 発声発語症状の経過を提示し, 発声の失行と捉えられ るのか,さらには発語失行との関連について検討した。

\section{症例}

症例は 50 歳, 男性, 右利き, 高卒の会社員 主訴：意識障害

現病歴：2001 年 1 月 3 日, 畑で倒れているところを 発見され，脳梗塞と診断され入院した。

既往歴：高血圧

神経学的所見：中等度意識障害, 左方への眼球共同 偏倚, 右中枢性顔面神経麻痺, 右方への舌偏倚, 上肢
優位の右片麻痺, 右バビンスキー徴候陽性, 右半身の 感覚障害を認めた。

神経心理学的所見：ささやき声を呈した発声障害, 発語失行, 口舌顔面失行, Broca 失語, WAB の失語指 数 65.4, レーヴン色彩マトリシス検査 23 点であった。

放射線学的所見：発症約 1 力月後の頭部 MRI（図 1) では, 左中心前回・中心後回, 島の皮質㤃よび皮 質下を中心に梗塞を示唆する所見が認められた。

発声発語症状の経過：発症より約 1 力月間は, 緘黙 であった. その後無力性のささやき声が見られるよう になったが, 発語開始困難, 構音の詋りといった発語 失行の症状が明らかであった。笑った際に有響成分が 認められた，意図的な咳払いは困難であったが，日常 場面では可能であり, 意図性と自動性の解離が見られ た。

3 力月後, 発語失行, 失語症は除々に改善し, 短文 レバルの音読や復唱, 簡単な自発話も可能となり流暢 性が増大した。声質は無力性が少なくなるも，依然と

してささやき声であった。

5 力月後, ささやき声に時折有響成分が混在するよ うになった。

6 力月後, 有声の頻度が多くなったが, 一貫性に乏 しかった. 表 1 に発症後 4 力月と 6 力月における標準 失語症検査 (SLTA)の一部を示す。このように文レべ ルの発話では, 完全にささやき声となるときと, 部分 的に有声となるとき，完全に有声になるときとがあっ た。なお有声時には，声を持続させようと力を入れ， 声質は努力性であった。

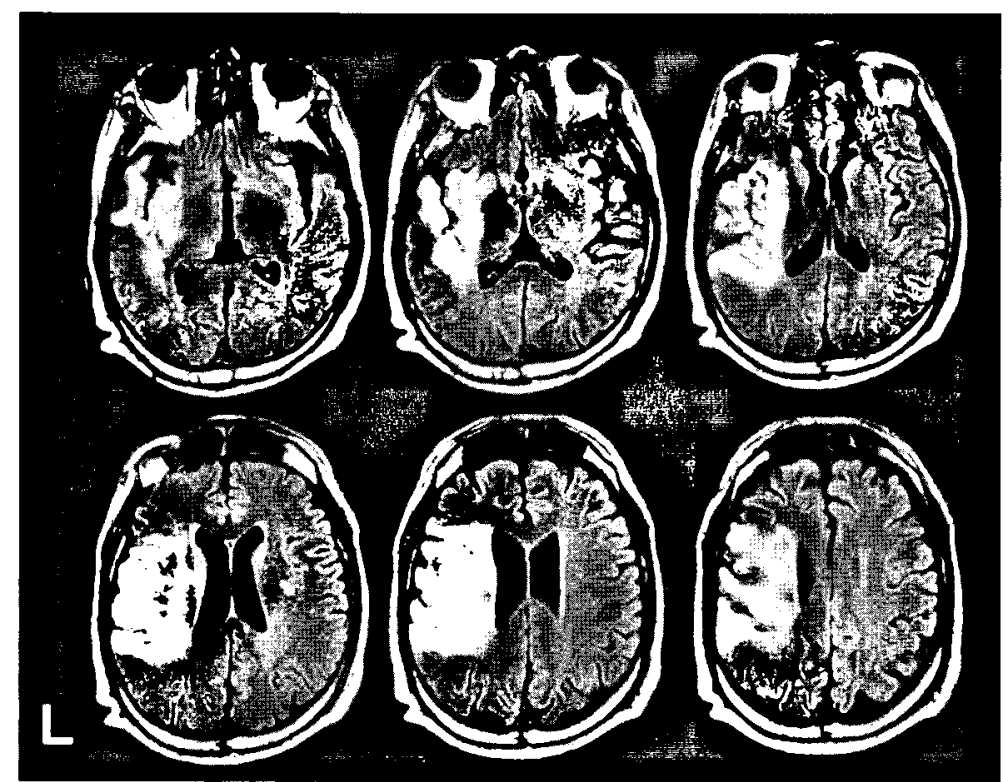

図 1 頭部 MRI 
け心因性失声症との鑑別が重要である。表 3 に典型的 な心因性失声症の一般的な特徴を示す。本例と比較す ると, 共通する特徵と明らかに異なる特徵とがあり, 本例の発声障害を心因性失声症としては考えにくい.

発声の高次中枢：猫，サル，ヒトでの実験報告があ $3^{21-23)}$.なかでも軍司 ${ }^{24)}$ は, 脳磁図にてヒトが発声する 際の喉頭調節が中枢の準供過程へ及ぼす影響について 検討している，その結果，前頭葉後部㧍よび島の領域 に発声の運動企画や声区の変換様式の相違を反映する 特異な活動が得られたことを報告している。この領域 を発声の高次中枢とするならば，本例の発声障害も， この領域の損傷により声帯の高次な運動企画が障害さ れ発声失行を呈したとも考えられる。

これまでに発声の失行と考えられた症例の報告は 4 例ある (表 4 )。全例とも右利きであり，3 例は左半球 損傷， 1 例は右半球損傷である. 病巣の広がりについ ては，本例が最も限局している。

発声障害の特徵については, Marshall ら ${ }^{14)}$, 小嶋 ら ${ }^{15)}$ のうに，発声の開始が著しく困難であるもの， Sieron $~^{16)}$ の構音に呼気の流出が見られないもの, 本 例のささやき声であるものなどさまざまである．意図 性と自動性の解離については，本例と小嶋ら ${ }^{15)}$ に報告 されているが，非一貫性については，本例のような有 声・ささやき声の不規則な混在や，同じ発話で一定し

表 3 本例と心因性失声症との比較

\begin{tabular}{lc}
\hline \multicolumn{1}{c}{ 一般的な心因性失声症の特徵 } & 本例 \\
\hline ・喉頭運動に器質的疾患がない & + \\
・意図的な発声時にはささやき声となる & + \\
・咳払いや笑うときには有響音声となる & + \\
・一貫性がある & - \\
・意図的な発声時以外の喉頭運動が正常である & - \\
・発症に関連する心因の存在が疑われる & - \\
\hline & + : 有, - - 無
\end{tabular}

ない,といった報告はこれまでに見られない。

発声障害の持続期間については, 全例で 8 力月上, 慢性的に及んでいる。このことは，上述した Darley や Aronson らの見解, すなわち発声失行は発語失行の急 性期に起こりうる一過性の症状とは異なることを示唆 している.

Marshall ${ }^{14)}$ の症例は, 当初発語失行, Broca 失語 に類似した発話の障害が見られたが，電気喉頭を使用 するとこれらが改善し正常な発話になったとしてい る. 本例は電気喉頭を使用しても構音レベルの失行に 改善は見られなかった。

\section{結＼cjkstart語}

本例の発声障害は, 発声の失行と捉えられ, 声帯運 動コントロールの高次中枢が障害されたものと考えら れる. 本例は従来の発語失行を合併している点で, 発 語失行の何らかの関与を否定はできないが，少なくと も発語失行例のなかに, 発声レベルでの障害が強い場 合があるということは明らかである。

最後に本例は, 意図的な咳払いや深呼吸といった発 声時以外の呼吸と声帯調節の夕イミングにも障害が見 られていた.この点からは, 喉頭運動失行という概念 についても今後検討できるかと思われる。

謝辞 本シンポジウムでの発表, 論文の作成にあたり, 御指 導いただきました筑波大学の吉岡博英教授ならびに昭和大学の 河村 満教授に深謝いたします.

\section{文献}

1) Darley, F.L. : Apraxia of speech ; 107 years of terminological confusion. Paper presented at the 44th annual convention of the American Speech and Hearing Association, 1968.

2）笹沼澄子，伊藤元信：Apraxia of Speech一その臨床像と

表 4 発声の失行と考えられた報告例

\begin{tabular}{|c|c|c|c|c|c|}
\hline 報告者 & 発声障害の特徵 & 持続時間 & 発語失行 & 失語症 & 病巣 \\
\hline Marshall ら (1988) & $\begin{array}{l}\text { 発声持続 } 2 \text { 3 秒 } \\
\text { 発声開始困難 } \\
\text { ささやき声/喉詰め発声 }\end{array}$ & 12 力月以上 & - & - & $\begin{array}{l}\text { 左前頭側頭葉, 側頭後頭葉 } \\
\text { 皮質および皮質下 }\end{array}$ \\
\hline 小嶋ら（1991） & $\begin{array}{l}\text { 意図/自動性の解離 } \\
\text { 呼気のみの流出 } \\
\text { 発声開始困難 }\end{array}$ & 12 力月以上 & + & + & 左前頭頭頂側頭葉 \\
\hline Sieron ら (1995) & 呼気流を伴わない & 3 年以上 & - & - & 右側頭頭頂葉 \\
\hline 本例 & $\begin{array}{l}\text { 意図/自動性の解離 } \\
\text { 非一貫性 } \\
\text { ささやき声＼cjkstart努力性 }\end{array}$ & 8 力月 & + & + & $\begin{array}{l}\text { 左中心前回後回下部 } \\
\text { 島の皮質および皮質下 }\end{array}$ \\
\hline
\end{tabular}


障害機構をめぐって。精神医学, $23: 1025-1032,1981$.

3) Schiff, H.B. and Alexander, M.P. : Aphemia, clinicalanatomic correlations. Arch Neurol, 40:720-727, 1983.

4) Dronkers, N.F.: A new brain region for coordinating speech articulation. Nature, 14:159-161, 1996.

5) 河村 満：神経学 (Neurology)の立場からみた構音障害一 特に Broca 野周辺病巣における構音の異常について一. 音 声言語医学, 31：235-241, 1990.

6) 荒木重夫, 河村 満, 塩田純一, 他：両側中心前回下部病 巣による純粋語啞. 失語症研究, 10：110-119, 1993.

7) Katharine, O., Malcolm, R.M., John, C.R., et al: Perceptual characterisitics of consonant production by apraxic speakers. JSHD, $55:$ 345-359, 1990.

8) Richard, J. and Jerry, V.: Articulatory and phonological aspects of consonant substitutions in apraxia of speech. Cortex, 15:451-470, 1979.

9）杉下守弘, 紺野加奈江, 加部澄江, 他：純粋語啞の二症例 の音声学的分析. 失語症研究, $5: 42-53,1985$.

10）春原則子, 宇野 彰：失語症における各発話モダリティで の音の誤反応分析一呼称, 復唱, 漢字音読, 仮名音読間で の比較一. 失語症研究, $13: 247-255,1993$.

11) Kent, R.D. and Rosenbek, J.C. : Acoustic patterns of apraxia of speech. JSHR, 26:231-249, 1983.

12) 伊藤元信, 笹沼澄子, 牛島達次郎, 他: 発語失行症におけ る発話時の構音器官の動態一ファイバースコープおよび $\mathrm{X}$ 線マイクロビームシステムによる観測—. 音声言語医 学, 19:285-296, 1978.

13）待井典子, 宇野 彰：発語失行例における発話の音響学的 分析一発話所要時間, 語頭子音の最大音圧, 基本周波数の 変動に関する検討. 失語症研究, 19：208-217，1999.

14) Marshall, R.C., Gandour, J. and Windsor, J.: Selective impairment of phonation: A case study. Brain and Language, $35: 313-339,1988$.

15）小嶋知幸, 宇野 彰, 加我君孝, 他: 意図的発声の重篤な 障害を呈した 1 例. 神経心理学, 7：149-156, 1991.

16) Sieron, J., Westphal, K.P. and Johannsen, H.S.: Apraxie des Kehlkopfes. Folia Phoniatr. Logop., 47 : 33-38, 1995.

17) Aronson, A.E.: Clinical Voice Disorders, 3rd ed., Thieme, New York, 1990.

18）正木信夫, 辰巳 格, 笹沼澄子 : 発語失行症患者の単語ア クセント生成における調音器官と発声器官の協調運動の異 常. 音声言語医学, 31：186-194, 1990.

19) Liepmann, H.: Apraxie. Ergb Gesamte Med, 1 : 519-543, 1920.

20) Darley, F.L., Aronson, A.A. and Brown, J.: Motor Speech Disorders. Saunders, Philadelphia, 1975.

21) Kanai, $T$., et al : Localization of the central vocalization mechanism in the brain stem of the cat. Exp Neurol, 6 : 426-434, 1962.

22) Smith, W.K.: The functional significance of the rostral cingular cortex as revealed by its responses to electrical excitation. J Neurophysiol, 8:241-255, 1945.

23) Jürgens, U., Kirzinger, A. and von Cramon, D. : The effects of deep-reaching lesions in the cortical face area on phonation. A combined report and experimental monkey study. Cortex, $18: 125-140,1982$.

24）軍司敦子：運動関連脳電位の基礎と臨床応用 発声関連脳 磁場。臨床神経生理学, 31: 111, 2003.

別刷請求先： $=$ 187-8510 東京都小平市天神町 2-450 公立昭和病院リハビリテーション科 日向礼子 